\title{
Feasibility Evaluation Basis in Public Buildings
}

공공건축 타당성 평가기준

Noh, Byung-Ok 노병옥 (도시경영연구원장)

지방자치제 실시 이후, 지방자치단체에 의한 투자사업이 지속적으로 늘어나고 있으나 지방자치단 체의 투자사업에 대한 합리적이고 체계적인 관리가 미흡하여 투자사업이 비효율적으로 추진되는 사 례가 빈번히 발생하고 있다. 특히 열악한 재정상황에도 불구하고 지방자치단체장들이 사업타당성 및 재원전망 등에 대한 면밀한 검증 없이 무리하게 사업을 추진하다가 중단되는 사례가 빈번히 발생 하고 있으며, 선심성·과시성·낭비성 사업이 졸속으로 추진되어 문제를 일으키기도 하였다. 이와 같 은 문제의 발생을 사전에 예방하기 위하여 현재 투자사업과 관련하여 다양한 평가제도들이 운영되 고 있다. 그러나 이러한 사전적 관리제도는 여러 이유로 인하여 소기의 성과를 거두지 못하고 있는 실정이다.

따라서 건전한 지방재정을 담보하고 투자심사제도의 효과성을 높이기 위해서는 우선 투자심사에 대한 심사기준이 보다 명확하게 정립될 필요가 있다. 아울러 투자심사에 대한 전문성 확보, 투자심 사 결과에 대한 이행력 확보 및 사후관리 등 전반적인 제도개선이 보다 합리적으로 이루어져야 할 것이다.

이와 같은 관점에서 공공건축에 있어 현행 투자심사제도의 현황 및 운영 실태를 분석하여 보다 합리적인 타당성 평가기준의 개선방안을 제안하고자 한다.

범위는 정부 및 지방자치단체에서 건립하는 모든 공공건축시설 중 국내 현행 법령이 정하는 사업 타당성 검토대상이 되는 건축물이다. 


\section{1. 현행 공공건축 타당성 평가기준의 한계}

\section{1 현행 투자심사제도의 선행연구}

변창흠·송우경은 현재의 타당성 투 자심사 평가기준이 조작적 정의 및 지 표화 부족, 평가기준의 전체적인 체계화 부족, 투자사업의 특성을 반영하지 않은 행정안전부 심사기준의 획일적 적용, 평 가기준의 낮은 활용도 등의 문제점을 안고 있다고 지적하였다. 또한 설문조사 의 실시 결과 사업부문별 평가기준의 차별화에 대해서 공무원의 $71 \%$, 전문가 의 $88 \%$ 가 필요성을 인정하고 있다 ${ }^{1)}$ 고 하여 다양화 및 차별화는 전문가와 공 무원 모두 대체로 필요성을 공감하고 있다고 강조하고 있다.

또한 이성근외 2명은 대부분 전 사업 에 공통적으로 적용하는 일률적 평가기 준만을 설정하고 있어 사업의 유형별 특성과 지역별 특성을 체계적으로 반영 하기 어렵고 정책적·직관적 판단에 의 존함으로써 투자심사의 객관성을 저하 시키며, 재원의 합리적 배분이 이루어지 지 못하고 있어, 심사방법이 정성분석 중심으로 이루어져 투자심사의 객관성 을 저하시키고 있을 뿐 아니라 사업특 성에 따른 가중치 적용이 이루어지지 못하고 있다2)고 언급하고 있다.

이와 같이 투자심사제도는 지방투자 사업의 사전적 평가제도로서 기능이 미 약한 실정이다. 이는 투자심사 시 사업 에 대한 재원조달계획에 대한 검토가 미흡했거나, 투자우선순위 검토가 제대 로 이루어지지 않는 등 투자심사제도가 지방투자사업에 대한 사전적 평가제도 로서의 기능을 발휘하지 못하기 때문인 것으로 사료된다.
[표 1] 공공건축물 건립사업 진행 현황

\begin{tabular}{|c|c|c|c|c|c|c|c|c|}
\hline \multirow{2}{*}{$\begin{array}{l}\text { 년 } \\
\text { 도 }\end{array}$} & \multicolumn{4}{|c|}{ 타당성 검토 보고서 } & \multirow[b]{2}{*}{$\begin{array}{l}\text { 완 } \\
\text { 공 }\end{array}$} & \multirow{2}{*}{$\begin{array}{l}\text { 추 } \\
\text { 진 } \\
\text { 충 }\end{array}$} & \multirow[b]{2}{*}{ 보 } & \multirow{2}{*}{$\begin{array}{l}\text { 반 } \\
\text { 려 }\end{array}$} \\
\hline & 공공건축물 명 & $\begin{array}{c}\text { 재무 } \\
(B / C)\end{array}$ & $\begin{array}{c}\text { 경제 } \\
(\mathrm{B} / \mathrm{C})\end{array}$ & $\begin{array}{c}\text { 할인율 } \\
\text { (\%) }\end{array}$ & & & & \\
\hline \multirow{4}{*}{$\begin{array}{l}2 \\
0 \\
0 \\
2\end{array}$} & 체육문화센터 & - & 1.31 & 15.0 & $\sqrt{ }$ & & & \\
\hline & 소방서 재건축 & - & $(-)$ & - & $\sqrt{ }$ & & & \\
\hline & 청소년 수련관 & - & 1.00 & 4.83 & $\sqrt{ }$ & & & \\
\hline & 소방서 재건축 & - & - & - & $\sqrt{ }$ & & & \\
\hline \multirow{15}{*}{$\begin{array}{l}2 \\
0 \\
0 \\
3\end{array}$} & 공무원수련원 & - & 1.4 & 6.0 & $\sqrt{ }$ & & & \\
\hline & 역사박물관 & 0.05 & 1.20 & 6.0 & & & $\sqrt{ }$ & \\
\hline & 관상복합타워 & - & - & - & $\sqrt{ }$ & & & \\
\hline & 종합사회복지관 & - & 1.98 & 7.0 & & & & $\sqrt{ }$ \\
\hline & 복지관 & - & 1.02 & 6.0 & $\sqrt{ }$ & & & \\
\hline & 문화예술회관 & - & 1.05 & 6.0 & $\sqrt{ }$ & & & \\
\hline & 청소년수련관 & - & 1.13 & 6.0 & $\sqrt{ }$ & & & \\
\hline & 시민안전체험관 & - & 1.18 & 6.0 & $\sqrt{ }$ & & & \\
\hline & 효행원 건립사업 & 0.22 & 1.23 & 6.0 & & & $\sqrt{ }$ & \\
\hline & 민속공예촌 건립 & 0.17 & 0.50 & 6.0 & & & & $\sqrt{ }$ \\
\hline & 청사 신축 & - & $\bullet$ & - & & & & $\sqrt{ }$ \\
\hline & 문화예술회관 & 0.17 & 1.44 & 6.0 & $\sqrt{ }$ & & & \\
\hline & 청소년수련관 & 0.10 & 1.34 & 6.0 & $\sqrt{ }$ & & & \\
\hline & 다목적시설 건립 & 0.51 & 1.31 & 6.0 & $\sqrt{ }$ & & & \\
\hline & 여성프라자 건립 & 0.22 & 1.14 & 6.0 & $\sqrt{ }$ & & & \\
\hline \multirow{4}{*}{$\begin{array}{l}2 \\
0 \\
0 \\
4\end{array}$} & 복합청사 신축 & 0.12 & $(\bullet$ & 6.0 & $\sqrt{ }$ & & & \\
\hline & 도시모형 전시관 & 0.43 & 1.43 & 4.5 & $\sqrt{ }$ & & & \\
\hline & 청소년 유스타운 & - & 1.07 & 6.0 & & & & $\sqrt{ }$ \\
\hline & 종합사회복지관 & - & 2.24 & 4.5 & $\sqrt{ }$ & & & \\
\hline \multirow{10}{*}{$\begin{array}{l}2 \\
0 \\
0 \\
5\end{array}$} & 어린이도서관 & - & 2.55 & 4.5 & $\sqrt{ }$ & & & \\
\hline & 동청사 신축 & 0.68 & 1.36 & 4.5 & & & $\sqrt{ }$ & \\
\hline & 다목적 체육센터 & 0.46 & 1.28 & 4.5 & $\sqrt{ }$ & & & \\
\hline & 오페라하우스 & 0.19 & 0.27 & 4.5 & & $\sqrt{ }$ & & \\
\hline & 영어체험마을 & 0.41 & 1.56 & 4.5 & $\sqrt{ }$ & & & \\
\hline & 수련원 건립 & - & 1.33 & 4.5 & $\sqrt{ }$ & & & \\
\hline & 도시관리센터 & - & 1.04 & 4.5 & $\sqrt{ }$ & & & \\
\hline & 문화복지회관 & - & 2.29 & 4.5 & $\sqrt{ }$ & & & \\
\hline & 수도사업소청사 & - & 1.09 & 4.5 & $\sqrt{ }$ & & & \\
\hline & 박물관 건립 & 0.11 & 1.81 & 4.5 & & & $\sqrt{ }$ & \\
\hline \multirow{5}{*}{$\begin{array}{l}2 \\
0 \\
0 \\
6\end{array}$} & 문화시설 건립 & - & 1.65 & 4.5 & $\sqrt{ }$ & & & \\
\hline & 박물관 건립 & 0.08 & 1.30 & 4.5 & & & & $\sqrt{ }$ \\
\hline & 수련원 건립 & 0.21 & 1.17 & 4.5 & $\sqrt{ }$ & & & \\
\hline & 박물관 건립 & 0.21 & 0.65 & 7.0 & & $\checkmark$ & & \\
\hline & 시민문화센터 & 0.06 & (-) & - & & $\sqrt{ }$ & & \\
\hline \multicolumn{5}{|c|}{ 계 } & 26 & 3 & 5 & 5 \\
\hline
\end{tabular}

타당성보고서상 정성적편익 등 정책적타당성이 있다고 검토

1) 변창흠·송우경, '투자심사의 평가기준 및 평가방법 개선에 관한 연구', 서울시립대학교 도시행정학과 도시행정연구 제16집, 2001년, 115쪽, 46쪽.

2) 이성근·이환범·이관률, '지방투자심사 대상사업의 유형화와 평가기준 및 가중치 산정', 지방행정연구 제20권 제4호 (통권 67호), 2006.12, 5쪽, 9쪽. 


\section{2 공공건축사업 타당성검토 보고서의 분석}

본 분석 대상사업은 지방재정법에 의거 50 억 원 이상의 건축시설이 투융자심사 타당성 검토 의무 대상이 되었던 2002년부터 2010년을 기준으로 약 4전 전인 2006년까지의 기간 내 공공건축물 건립 타당성 검토가 이루어진 시설을 선정하였다. 이는 해당 건축시설에 대한 타당성 검토 심사 후 예산확 보기간, 설계기간, 공사기간, 완공 후 시운전 기간 그리고 입주 후 1 년 이상 운영·유지된 기간 등 총 4년 이상 경과하여야 사후평가를 할 수 있다고 판단하였기 때문이다.

이러한 선정기준에 의거 수집된 38건의 타당성 보고서를 대상으로 [표 1]과 같이 분석하였다. 이에 따르면 정성적 편익에 의해 경제성분석이 작성된 건은 주로 청사에 집중되어 있으며, 경제성 $\mathrm{B} / \mathrm{C}$ 는 문화, 예술, 박물관 시설 등은 $0.27 \sim 2.55$ 로 편차가 크게 나타났고 그 외의 시설들에서는 $1.02 ~ 2.24$ 로 나타나 상대적으로 고른 수치를 보였다.

재무성 $\mathrm{B} / \mathrm{C}$ 는 전체적으로 $0.05 \sim 0.68$ 을 나타냈으나 주로 '보류 및 반려'건의 경우 재무성의 평균이 0.10 인 반면에 '완공 및 추진중'건의 평균은 0.25 를 보였으며, 경제성 $\mathrm{B} / \mathrm{C}$ 나 사업비와는 무관한 것으로 나타나 대체로 경제적 파급효과 등과는 상관없이 재무성이 낮은 사업의 건은 투자심사에서 통과율이 낮은 것으로 분석된다.

한편 사회적할인율은 2002년도에는 정립되지 못하다가 2003년도에는 $6.0 \%$ 를 주로 이용하였고 2004 년도에는 $6.0 \%$ 와 $4.5 \%$ 를 혼용하다가 2005년도 이후에는 대체로 $4.5 \%$ 로 정립되어 현재에 이르 고 있는 것으로 분석된다.

[표 1]에서 열거된 보고서를 다시 사업추진과 진행상황에 따라 구분하여 [표 2]로 정리하였다. 이에 따르면 총 38 개의 사업 중에서 완공이 26 개(68\%), 추진 중인 사업이 3 개(8\%), 보류가 4 개(11\%), 그리 고 반려가 5 개(13\%)로 나타났다. 이는 타당성이 있다고 작성된 보고서 중 약 $24 \%$ 가 타당성 검토에 미흡하였다고 해석될 수 있다.

[표 2] 공공건축물 관련 사업 추진 여부

\begin{tabular}{c|c|c|c|c|c}
\hline 구 분 & 완공 & 추진 & 보류 & 반려 & 합계 \\
\hline 보고서수 & 26 & 3 & 4 & 5 & 38 \\
\hline 비율(\%) & 68 & 8 & 11 & 13 & 100 \\
\hline
\end{tabular}

\section{3 사후평가의 분석}

2002년부터 2006년까지의 공공건축물 관련 타당성조사 보고서와 사후평가의 비교분석을 통하여 변경요인을 파악하였다.

1) 중장기 지역계획 및 지방재정계획과의 연계성 측면

공공건축물 건립 사업은 특정 지역 또는 특정의 서비스를 주는 시설임에도 불구하고 정책성 분석 에 있어 특수평가 항목을 별도로 정하지 않고 여타 사업과 동일한 기준 하에 분석되었다.

재원조달 가능성 분석결과 각 공공건축물의 성격상 수익구조가 안정적이지 못하여 지방자치단체 의 재정지원을 필요로 하는 시설물이 많아 장기간 적자가 지속되고 있어 자체적인 재원발굴이 필요 한 것으로 나타났다.

실제 박물관 건립(2005) 사업은 문화재보호법의 저촉으로 인해 사업 중단으로 이어지고, 계획을 변경하여 재추진하였으나 박물관 예정부지에서 문화재가 발견되면서 건립불가 판정을 받았으며, 관 련예산의 확보에도 어려움이 있었다. 먼저, 박물관 사업이 지연되자 계획을 변경하여 추진하였고, '국 가지정 문화재 반경 $500 \mathrm{~m}$ 내 개발은 문화재보호법상 현상변경 허가를 받아야 한다'는 법해석 미흡으 로 인해 문화재청으로부터 불허판정을 받아 중단되었으며, 박물관 건립 예정부지에서 재실(齋室)터가 발견되면서 문화재 심의위원으로부터 다시 건립불가 판정을 받았다. 또한 단독 추진이 있었으나 사 
업비 및 부지를 확정하지 못해 불투명하였으며 관련 예산만 600 여억 원에 달해 정부나 도의 주도적 인 사업추진 의지와 예산 지원이 없을 경우 단독 사업추진이 불가능하게 되었다.

그리고 청소년 유스타운 조성(2004)사업은 기존의 정수장의 부지에 청소년유스타운, 임대주택, 영 어마을 조성 등 여러 계획이 검토되었으나 항공기 소음 등으로 인해 공공시설물 설치가 부적합 하다 는 의견이 제기 되어 최종적으로 공원 조성으로 변경 결정되었다.

또한 청사 신축(2003)사업은 2003년 타당성 조사를 하였으나, 2008년 1월 중앙정부의 직제개편으 로 인해 다른 기관과 통합하면서 하나의 행정기관으로 개편되어 청사 신축 계획은 폐기됐다.

한편, 민속공예촌 건립(2003)사업은 전통민속공예촌 조성사업을 위해 민간기업을 유치하여 사업을 추진하려 했으나, 부지 미확보, 민간자본 유치 실패, 중앙정부와의 정책 이견, 시의 소극적 행정 진행 등의 복합적인 요소로 결국 사업이 폐기되었다.

2) 재무적·경제적 수익성 측면

공공건축물의 유형별 특성에 따라 편익 및 비용 추정 규모의 상당한 변화가 불가피하므로 도출된 $\mathrm{B} / \mathrm{C}$ 비율이나 내부수익률 역시 절대적인 사업 경제성을 나타내기에는 한계가 있는 것으로 분석되었 다. 특히 편익 및 비용의 추정에 있어 일관성 있게 사용될 수 있는 기준이나 방침 없이, 연구진의 판단 에 크게 의존하고 있어 사업간 비교가 어렵고 절대적인 판단기준으로 적용하기에는 한계가 있는 것 으로 조사되었다.

[표 1]의 보고서를 경제성 분석을 근거로 세분화하여 [표 3]과 같이 재분류하였다.

[표 3] 공공건축물 관련 타당성 조사 년도 별 추진결과

\begin{tabular}{c||c|c|c|c|c|c||c|c}
\hline \multirow{2}{*}{ 연 도 } & \multicolumn{2}{|c|}{$\mathrm{B} / \mathrm{C} \geqq 1$} & \multicolumn{2}{c|}{$\mathrm{B} / \mathrm{C}<1$} & \multicolumn{2}{c||}{ 기 타 } & \multicolumn{2}{c}{ 계 } \\
\cline { 2 - 10 } & $\begin{array}{c}\text { 완공및 } \\
\text { 추진중 }\end{array}$ & $\begin{array}{c}\text { 보류및 } \\
\text { 반려 }\end{array}$ & $\begin{array}{c}\text { 완공및 } \\
\text { 추진중 }\end{array}$ & $\begin{array}{c}\text { 보류및 } \\
\text { 반려 }\end{array}$ & $\begin{array}{c}\text { 완공및 } \\
\text { 추진중 }\end{array}$ & $\begin{array}{c}\text { 보류및 } \\
\text { 반려 }\end{array}$ & 계 & $\begin{array}{c}\text { 통과율 } \\
\text { (\%) }\end{array}$ \\
\hline '02 & 2 & & & & 2 & & 4 & 100 \\
\hline '03 & 9 & 3 & & 1 & 1 & 1 & 15 & 67 \\
\hline${ }^{\prime} 04$ & 2 & 1 & & & 1 & & 4 & 75 \\
\hline${ }^{\prime} 05$ & 7 & 2 & 1 & & & & 10 & 80 \\
\hline '06 & 2 & 1 & 1 & & 1 & & 5 & 80 \\
\hline \hline 계 & 22 & 7 & 2 & 1 & 5 & 1 & 38 & 76 \\
(\%) & $58 \%$ & $18 \%$ & $5 \%$ & $3 \%$ & $13 \%$ & $3 \%$ & $100 \%$ & \\
\hline
\end{tabular}

2002년 2건의 보고서는 경제성 분석을 수치화하기 어려웠으나 정성적 분석을 통하여 경제성이 있 다고 판단하였고, 나머지 2 개의 공공건축물 건립 사업도 타당성이 인정된 후 완공을 하여 $100 \%$ 통과 율을 보이고 있다.

2003 년에는 15 건의 투자사업에서 $\mathrm{B} / \mathrm{C}<1$ 이 1건, 경제성 분석에서 정량적 분석 사업이 2건 있었 으며, 15 건 중 10 건의 사업이 타당성 평가를 통과하여 완공되었고 3 건의 사업은 $\mathrm{B} / \mathrm{C} \geqq 1$ 임에도 불구하고 사업 보류 및 반려로 이어졌다.

2004년의 공공건축물 건립 관련 사업 타당성 보고서를 보면, 4 건의 사업 중 1 건의 보고서에서 정 량적 편익을 통하여 경제성 있다고 하였으며, 3 건의 사업은 $\mathrm{B} / \mathrm{C} \geqq 1$ 로 경제성이 있다고 판단하였으 나 이 중 1 건의 사업은 반려 되었다.

2005년에는 10 건의 사업타당성 검토 중에서 1 건은 경제성 B/C Ratio 가 0.27 이여서 경제성이 낮 다고 하였으나 사업 추진 중이며, 나머지 9 건은 $\mathrm{B} / \mathrm{C} \geqq 1$ 로 경제성 있다고 하였으나 이 중 2 건의 사업이 보류 및 반려되었다. 
2006년에 5건의 타당성 보고서 중 1 건의 보고서에서 정성적 편익이 있다고 결론 낸 후 추진 중이 고, 1 건의 사업은 경제성이 0.65 로 낮게 평가되었으나 추진중에 있으며, 3 건의 사업은 $\mathrm{B} / \mathrm{C} \geqq 1$ 로 경제성 있다고 결론 내렸으나 1 건의 사업이 반려되었다.

이처럼 조사대상 사업의 경우 $\mathrm{B} / \mathrm{C}$ 가 실제 심사평가에서 미치는 영향도가 절대적이지 않았음을 알 수 있다. B/C Ratio $\geqq 1$ 임에도 불구하고 $18 \%$ 가 보류 및 반려되었고, B/C Ratio < 1 임에도 불구하고 추진 중인 건이 '보류 및 반려'보다 많았으며, 경제적 $\mathrm{B} / \mathrm{C}$ 가 명확치 않아 정성적 편익만 언급한 경우 에도 '보류 및 반려'보다도 오히려 완공 및 추진 중인 건이 더 많이 나타난 것으로 조사되었다.

3) 주민 숙원 수혜도 및 사업요구도 측면

낙후된 지역 인프라 구축 목적 사업에 대해서는 해당 지역 인프라의 질적 수준, 인프라 구축 실태, 해당 지역에서 중점적으로 추진하고 있는 특화산업과의 연계가능성 등을 제시하도록 하여 일반적인 $\mathrm{SOC}$ 사업의 지역균형발전 평가항목과 차별화 할 필요가 있었다.

사례로 청사 신축(2005)사업을 살펴보면 초기계획은 수영장이 포함된 주민센터의 건립을 추진하 려 하였으나, 예산확보의 어려움과 주민의 반대에 부딪혀 수영장을 없애고 현실성 있는 주민편의시 설 확충이라는 절충안으로 계획을 변경하여 시의 지원과 구의 예산확보에 따라 착공에 들어갔다. 이 는 주민들의 의견을 제대로 반영한 사업이라고 볼 수 없고, 예산 확보 및 재원조달 측면에서도 부적 절하게 이루어진 사업이라 할 수 있다. 그 추진 경위를 살펴보면, 구청장이 선거공약으로 주민센터에 수영장을 함께 건립하겠다고 내세웠으나 당선 후 구의 재정악화로 수영장을 뺀 순수한 주민센터 건 립으로 계획 변경하여 추진하였지만, 주민들의 반대에 부딪혀 주민센터에 헬스장 등 주민편의시설을 포함하여 건립하기로 결정하였다.

\section{2. 공공건축 타당성 평가기준의 문제점}

\section{1 획일적 심사기준}

지방자치단체의 투자심사는 행정안전부 지침에 따른 투자심사기준을 적용하고 있으나 투자사업은 그 종류가 다양하다. 예를 들면, 일반행정, 문화체육청소년관광, 청소환경상하수도, 사회보장보건, 주 택지역개발, 농수산개발, 지역경제개발, 국토자원보전개발, 도로교통, 민방위소방 등 투자사업의 성격 이 다양하다. 뿐만 아니라 사업의 특성에 따라 목적 및 효과가 상이하다. 예를 들면, 지방투자사업의 경우 공공성이 강한 사업이 있는 반면 수익성을 목적으로 하거나 고려한 사업이 있다. 또한 동일한 투자사업의 유형이라 하더라도 지역적 특성에 따라 투자사업의 목적과 파급효과가 다르게 나타난다.

때문에 심사기준과 심사방법에서 이러한 요소들이 반영되어야 함에도 불구하고 현재의 투자심사 기준은 모든 사업에 대하여 행정안전부 지침상 7 가지의 동일한 심사기준만을 설정하고 있어 사업유 형별 특성과 지역별 특성이 반영되지 못하고 있다.

투자심사 최종평가에서 사업의 필요성·시급성 기준의 활용도는 높지만3) 나머지 기준은 활용성이 낮게 나타나고 있다. 이는 결국 투자사업의 사업제안서로부터 투자심사에 이르기까지 필요한 다양한 정보를 제공해 주지 못하는 문제점을 갖고 있어 최종 투자심사결정단계에서 다양한 평가기준을 고려 하지 못하고 일부 평가기준에 의해 결정되는 양상을 타나내고 있는 것으로 조사되었다.

\section{2 객관성 결여}

투자심사의 평가방법은 평가기준에 따라 정량적 방법과 정성적 방법으로 평가됨이 바람직하다. 현 행 기준으로 살펴보면 국가계획-정책과의 부합성, 지방재정계획과의 연계성은 정성적 평가방법으로, 경제적·재무적 수익성, 재원조달과 원리금 상환계획, 사업계획의 적정성은 정량적 평가가 가능하다.

3) 행정안전부의 7 개 평가 기준 중에서 활용비중이 가장 높은 $96.5 \%$ 로 조사되었음. 
그리고 주민수혜도·사업요구도, 사업의 필요성·시급성은 지표화를 통한 정량적 방법으로 평가할 수 있다. 그러나 현행 투자심사 방법은 주로 주관적 정성평가 위주로 이루어지고 있다는 문제점이 나타 났다.

또한 정량적 분석의 핵심은 재무적·경제성 분석의 평가기준이다. 재무적·경제성 평가는 투자사업 의 발생수익, 투자비와 유지관리비 추정, 할인율을 통한 수익과 비용의 현가화 추정 등이 이루어져야 하고, 순현가(NPV), IRR, B/C Ratio 등의 계량적 평가도 이루어져야 한다. 투자사업의 평가과정에서 재무적·경제적 분석의 평가기준은 그 역할을 다하지 못하는 형식적인 평가기준이 되고 있는 경우가 많은 것으로 조사되었다.

한편, 지방자치단체의 중장기 발전계획 및 중기재정계획의 불완전성 및 변동성을 고려 할 때, 또는 정책적으로 긴급하고도 중요한 사업이 발생할 경우도 있어 모든 투자사업을 중기지방재정계획에 반 영하고 투자심사를 거쳐 예산에 반영하는 데는 한계가 있다. 그러나 특별한 이유 없이 정치적인 결정 으로 중기재정계획에 미 반영된 사업들이 투자심사를 받거나, 먼저 투자심사를 받고 후에 중기재정 계획에 반영하는 사례가 있어 투자사업의 전반적인 계획성 및 일관성에 문제가 있는 것으로 조사되 었다.

이러한 객관성의 결여는 결국 사후관리에도 영향을 미쳐, 사업의 비계획성, 투자심사의 소홀 등의 원인에 의한 사업변경, 재원조달의 어려움, 민원제기 발생가능성 등의 문제점으로 이어지고 있는 것 으로 분석되었다.

\section{3. 공공건축물 타당성 평가기준의 개선방안}

타당성 평가항목의 다양성을 위해 여러 사업의 특성을 반영하고 지속가능성 관점에서 다각적인 검토를 하기 위해서는 새로운 시각의 평가기준이 제시되어야 한다. 이에 획일화된 평가기준에 대한 한계를 극복하고 실무 적용가능하며 미래지향적인 평가기준을 위해 생애주기를 고려한 평가기준을 제안하고자 한다.

\section{1 공공건축 타당성 생애주기 평가기준의 제안}

현행 타당성 심사평가기준의 문제점으로 획일화되고 다양하지 못한 평가항목들을 보완하기 위해 서는 다양한 평가기준의 정립이 필요하다. 이에 타당성 평가에 사용되는 평가항목들의 문제점을 개 선하고 공공건축물 건립 타당성평가와 관련하여 적정한 평가기준을 선정하기 위해서 우리나라의 현 행 타당성 평가제도에서의 평가항목을 기준으로 신공공관리론(NPM)4)에 의한 공공건축 경영전략에 사용된 평가항목들을 정리하여 보다 다양한 평가기준을 마련하고자 한다. 이러한 평가기준을 설정하 기 위하여 그간의 건립 전 초기투자 중심의 보수적 관점에서 탈피하여 적극적이고 지속가능한 미래 지향적 관점에서 새로운 생애주기(LC : Life Cycle)를 고려한 평가항목을 제안한다.

공공건축의 목적은 그 시설을 통해서 국민이나 주민의 이익, 공공 서비스를 제공하는 것에 있다. 따라서 사람들이 그 시설을 목적에 따라 편리하고 쾌적하게 이용할 수 있고 낭비 없이 효율적으로 활용하여야한다.

이 명쾌한 목적이 있음에도 종적관계 행정이나 시설관리자의 경영의식의 결여로 인해 공공 서비스 의 변화에 공공건축이 따라가지 못하는 실정이다. 이러한 이유로 공공건축은 비효율을 안고 있으며

4) 신공공관리론은 시장의 실패를 치유하기 위한 정부개입이 정부가 감당할 수 없는 수준의 행정수요 유발과 정부업무 과부하를 초래함에 따라 발생하는 정부실패에 대한 대응책으로 1980년대부터 미국과 영국을 중심으로 시장주의와 신관리주의에 입각하여 대두된 행정관리방안이다. 한편 신공공관리론에서 지향하는 고객만족은 정부가 공공서비스 의 이용자인 시민을 고객으로 인식하고 이들의 요구에 적극적·효율적인 방식으로 대응하면서 행정서비스의 선택과 평가기회를 고객에게 부여한다는 것을 의미한다. 
그 목적을 충분하게 완수하지 못하고 있다. 현재는 참살이를 위한 환경문제 등을 포함하여 다양한 요구를 공공서비스에 기대하고 있다.

이에 공공건축의 타당성 평가지표를 정할 때 신공공관리론에 의한 공공건축 경영전략[5]으로 경영 의 관점, 재무의 관점, 부동산의 관점, 운영관리의 관점, 환경안전위기관리의 관점, 법무의 관점, 설명 책임의 관점의 8 가지 관점에서 평가항목을 도입하였다.

1) 초기투자 중심의 평가항목

현재의 행정안전부 및 서울시 투융자심사기준을 기초로 초기투자 중심의 관리항목을 [표 4]와 같 이 정리하였다.

현행 타당성 평가기준은 대부분 초 기투자 중심의 평가항목으로 구성되 어 있는 바, 이에 대한 검토는 충분히 이루어지고 있어 추가로 별도의 평가 항목이 필요해 보이지는 않다고 판단 된다.

2) 위험관리 중심의 평가항목

현행 재정사업 투자심사의 평가항 목에 신공공관리론에 의한 공공건축 경영전략의 평가기준에 의거 건립 중 의 적극적인 위기관리 관점에서 [표 5] 와 같이 평가항목을 선별 하였다.

신공공관리론(NPM)의 공공건축 경 영전략에서 3 개의 항목을 도입하였는 데, '주민과의 의견교환체계'는 지방자 치단체가 지향하는 주민으로의 접근 을 위한 노력을 적극적으로 견지해야 한다는 관점에서 도입하였다. 사업 서비스에 대한 주민의 만족도 극대화 를 위해서는 주민에 대한 정보공개와 주민과의 쌍방향 커뮤니케이션이 필 요하다.

'위기관리 대책의 평가'는 자연현상 등 천재지변, 인위적으로 예측치 못한 상황, 자금의 미순환 등이 있는데 일 반적으로 바람직하지 않은 사건이 발 생할 가능성이 있는지, 발생 시 그 피 해 범위 및 규모와 피해의 정도 및 이 에 따른 매뉴얼 등 위기 관리 대책의 수립이 있어야 할 것이다.

마지막으로 '근린 관련의 분쟁방지' 는 건축단계에서의 각종 민원, 환경파 괴로 인한 $\mathrm{NGO}$ 단체들의 집단항의 등 에 대비한 대책이 작성되어 있어야 한 다는 관점이다.

[표 4] 초기투자 중심의 평가항목

\begin{tabular}{|c|c|c|}
\hline 평가기준 & 세부평가항목 & 비고 \\
\hline \multirow{3}{*}{$\begin{array}{l}\text { 국가장기 계획 및 } \\
\text { 경제사회 정책과 } \\
\text { 부합성 }\end{array}$} & 정부의 국토종합개발계획과 연계성 & \multirow{3}{*}{ 행안부 } \\
\hline & 국가경제사회발전계획이 동 계획과의 연계성 & \\
\hline & 각 중앙부처가 추진하는 역점시책과의 연계성 & \\
\hline \multirow{2}{*}{$\begin{array}{l}\text { 중장기 지역계획, } \\
\text { 지방재정 계획 } \\
\text { 연계성 }\end{array}$} & 개별 법률의 지역단위계획과 관련성 & \multirow{2}{*}{ 행안부 } \\
\hline & 중기지방재정계획에의 포함 여부 & \\
\hline \multirow{2}{*}{$\begin{array}{l}\text { 소요자금 조달 및 } \\
\text { 원리금 상환능력 }\end{array}$} & 국고보조사업 해당 여부 및 부담비율 적정성 & \multirow{2}{*}{ 행안부 } \\
\hline & 원리금 상환 등 재원조달 능력 & \\
\hline \multirow{2}{*}{$\begin{array}{l}\text { 사업의 필요성 및 } \\
\text { 시급성 }\end{array}$} & 타사업보다 시급히 추진해야 할 필요성 & \multirow{2}{*}{ 행안부 } \\
\hline & 현재 수요추세 등 예상 수요도 & \\
\hline \multirow{2}{*}{$\begin{array}{l}\text { 주민숙원. 수혜도 및 } \\
\text { 사업 요구도 }\end{array}$} & 주민의 사업요구 정도, 수혜 지역 및 주민수 & \multirow{2}{*}{ 행안부 } \\
\hline & 사업목표치 대비 사업성과 수준 대비 & \\
\hline $\begin{array}{l}\text { 사업규모와 } \\
\text { 사업비의 적정성 }\end{array}$ & 수혜인구, 규모사업비 적정산출 & 행안부 \\
\hline \multirow{3}{*}{$\begin{array}{l}\text { 지역간 균형 및 } \\
\text { 입지 타당성 }\end{array}$} & 유사사업과의 중복여부 & \multirow{3}{*}{ 서울시 } \\
\hline & 지역간 균형성 & \\
\hline & 시설입지의 타당성 & \\
\hline
\end{tabular}

[표 5] 위험관리 중심의 평가항목

\begin{tabular}{l|l|c}
\hline \multicolumn{1}{c|}{ 평가기준 } & \multicolumn{1}{c|}{ 세부평가항목 } & 비고 \\
\hline $\begin{array}{l}\text { 주민숙원· 수혜도 및 사업 } \\
\text { 요구도 }\end{array}$ & 주민과의 의견교환체계 & NPM \\
\hline \multirow{2}{*}{ 환경 및 제약요인 대책 } & 위기관리 대책의 평가 & \multirow{2}{*}{ NPM } \\
\cline { 2 - 3 } & 근린관련의 분쟁 방지 & \\
\hline
\end{tabular}

[표 6] 운영관리 중심의 평가항목

\begin{tabular}{|c|c|c|}
\hline 평가기준 & 세부평가항목 & 비고 \\
\hline \multirow{4}{*}{ 재무적· 경제적 수익성 } & 자치단체에 미치는 재무적 수익성 & \multirow{2}{*}{ 행안부 } \\
\hline & $\begin{array}{l}\begin{array}{l}\text { 지역에 미치는 경제적 수익성 } \\
\text { (파급효과) }\end{array} \\
\end{array}$ & \\
\hline & 생애주기비용 (LCC,) & \multirow{2}{*}{ NPM } \\
\hline & 자산 건물가치 평가 & \\
\hline $\begin{array}{l}\text { 주민숙원· 수혜도 및 } \\
\text { 사업요구도 }\end{array}$ & 주민과의 의견교환체계 & NPM \\
\hline \multirow{2}{*}{ 운영관리의 적정성 } & 운영조직 및 운영형태의 적합성 & \multirow{2}{*}{ 서울시 } \\
\hline & 시설활용계획 및 주요 사업내용 & \\
\hline $\begin{array}{l}\text { 사업규모와 사업비 } \\
\text { 적정성 }\end{array}$ & $\begin{array}{l}\text { 수요추세 등 발전전망을 고려 } \\
\text { 분석 }\end{array}$ & 행안부 \\
\hline 환경 및 제약요인 대책 & 지구환경대책의 평가 & NPM \\
\hline
\end{tabular}


3) 운영관리 중심의 평가항목

건립 후의 운영관리 중심으로 장기적이고 연속적이며 지속가능성의 관점에서 [표 6]과 같이 5개 분야 9 개 평가항목을 인용하였는데, 행정안전부의 3 개 항목, 서울시의 2 개 항목, NPM의 4 개 항목으 로 구성하였다.

건립 완공 후 운영유지비의 지속가능성 관점에서 인용한 '생애주기비용'항목에 대하여 현재의 국 내 타당성 평가항목으로 재무적 경제적 분석은 주로 수익성에 기반을 두고 있는 반면에 본 항목은 비용의 입장에서 적극적으로 고려되어야 할 항목이며, '자산의 건물가치 평가'항목은 건축시설물 뿐 만이 아니라 토지에 대해서도 향후 이용가치를 고려하는 민간경제에서 주로 이용하는 부동산의 관점 에서 적극적으로 도입하였다.

또한 '주민과의 의견교환체계' 항목은 건립중 적극적인 위험관리의 관점인 동시에 건립 후 지속가 능성 관점의 운영관리방안이기도 하다. 행정서비스에 필요한 사업이 주민에 대해서 만족도를 높이기 위해서는 주민의 의견을 반영하는 것이 필요한데 그 방법으로 공공참여(Public Involvement)방식과 워크샵(Workshop)방식이 있다. 이러한 방식을 사용해서 계획 실시의 과정에서 정보를 주민에게 공개 함과 동시에 의견을 청취하고 반영시키는 구조가 이루어져야 한다. 홈페이지에 의견 수렴 코너를 만 들거나 설명회의 개최와 자료의 공개 등 주민과의 만남을 많이 가지고 주민의 의견 및 요구에 대해서 행정적으로 회답을 하고 논의되어 질수 있도록 주민과의 쌍방향의 의견 교환을 가능하게 하는 환경 체제가 필요하다.

한편 '지구환경 대책의 평가'항목에 대해서는 이전의 건축분야에 있어서의 '환경'이 실내 쾌적성의 향상을 목 표로 하는 '실내환경'을 가리키고 있었지만, 1960년대의 공해 방지, 1970년대의 오일쇼크로 인한 에너지절약 운 동을 거쳐, 오늘에 이르러 '환경'이 가리키는 의미는 '실내 환경+주변환경'으로 그 범위가 넓어짐에 따라 이에 대한 적극적인 대처를 해야 할 필요가 절실해 본 항목을 도입 하였다.

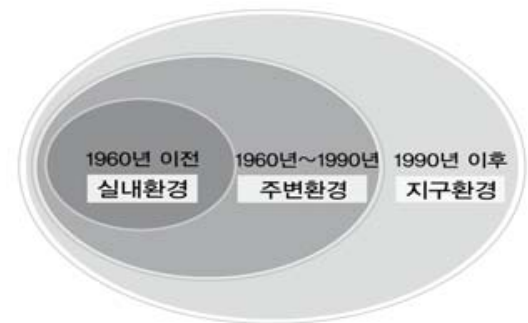

[그림 1] 환경안전위기관리 관점의 사고방식

\section{2 생애주기 세부평가항목의 지표기준}

투자사업을 결정함에 있어서 경제적 합리성보다 정책적 의사결정이 우선시 되는 경우가 많은 것이 사실이다. 투자심사가 합리적이고 객관적으로 이루어 질 때 이에 따른 심사결과도 신뢰성이 확보되 고 정치적 여건 등에 흔들리지 않고 일관성 있게 추진될 수 있다고 생각된다. 또한 투자심사 기준의 획일화와 비계량적 평가기준이 정성적 분석의 원인이 되고 있다고 판단되기에, 이러한 문제점을 해 결하고 평가항목의 객관성을 유지하기 위한 계량적 지표기준은 의미가 있다고 판단된다.

세부평가항목의 계량화를 위하여 현재 각 지자체에서 사용하고 있는 지표 및 전문가 의견을 통하 여 지표기준을 제안하였다.

1) 초기투자 중심의 평가항목 지표기준

[표 4]의 세부평가항목에 대하여 지표기준을 정리하여 [표 7]과 같이 나타내었다.

'국고보조사업 해당여부 및 부담비율 적정성' 항목은 해당사업에 대하여 자치단체에서의 국고부담 비율에 대한 해당사업의 일반적 평균 국고부담비율을 적용하여 배점을 부여할 수 있을 것이며, 국고 부담에 대한 의존율이 낮을수록 해당 사업을 추진할 수 있는 능력이 높은 것으로 이해해 볼 수 있다. 또한 '원리금 상환 등 재원조달 능력' 항목은 해당 사업에 대한 총사업비에 대하여 순수하게 자체적으 로 확보할 수 있는 재원에 대한 비율을 평가지표로 활용할 수 있을 것이다. 
[표 7] 초기투자 중심의 평가항목 지표기준

\begin{tabular}{l|l}
\hline \multicolumn{1}{c|}{ 세부평가항목 } & \multicolumn{1}{c}{ 지표기준 } \\
\hline 정부의 국토종합개발계획과 연계성 & 반영, 미흡, 미반영 \\
\hline 국가경제사회발전계획과의 연계성 & 반영, 미흡, 미반영 \\
\hline 중앙부처 역점시책과의 연계성 & 반영, 미흡, 미반영 \\
\hline 개별 법률의 지역단위계획과 관련성 & 관련 있음, 보통, 관련 없음 \\
\hline 중기지방재정계획에의 포함 여부 & 포함, 미흡, 미포함 \\
\hline 국고보조사업 해당 여부 및 부담비율 & 해당사업 국고부담 의존율 \\
\hline 원리금 상환 등 재원조달 능력 & 재원조달비율 \\
\hline 시급히 추진해야 할 필요성5) & 긴급사업, 조속사업, 대체사업, 일반사업 \\
\hline 수요추세 등 예상 수요도 & 인구추이, 시설이용현황, 보급률, 수혜인구, \\
\hline 사업요구 정도, 수혜 지역 및 주민수 & 수옝도, 민원발생빈도 \\
\hline 사업요구도: 자치단체의 사업목표치 대비 사업성과 수준 대비 & 사업성과지표(사업성과 수준/목표치) \\
\hline 수혜인구, 규모사업비 적정산출 & 동등사업 규모사업비 적정 정도 \\
\hline 유사사업과의 중복여부 & 기준 인구당 면적 비교(국외 및 타 시도비교) \\
\hline 지역간 균형성 & 공공건축시설의 인근 위치 \\
\hline 시설입지의 타당성 & AHP분석을 통한 점수(순위별 점수 차등 부여) \\
\hline
\end{tabular}

'타 사업보다 시급히 추진해야 하는 사유 또는 필요성' 항목의 평가지표는 현재 서울시를 비롯하여 충청남도 및 여러 지자체에서 활용하고 있는 4단계의 평가지표를 제시하였고, '현재 수요추세 등 사 업의 성격 분석 및 예상 수요도' 항목과 관련한 수요에 관련된 지표가 현재 가장 다양한 형태로 사용 하고 있으며 활용도도 매우 높게 나타나고 있었다.

'사업에 대한 주민사업 요구도, 사업시행 수혜지역 및 주민수' 항목은 해당 총인구 대비 수혜인구의 비를 평가지표로 사용할 수 있을 것이며, 민원의 발생빈도 및 집단민원의 발생 여부에 따른 지표를 더불어 활용할 수 있을 것이다.

또한 '유사사업과의 중복여부' 항목은 단지 인근에 유사 건축시설의 유무만을 검토할 것이 아니라 수요의 충족도 여부가 더 중요한 관건이 될 수 있는 것으로 조사되었다. 그리고 '지역간 균형성' 항목 에서 공공건축시설의 인근 위치는 도보권역 등을 기준으로 1차·2차·3차 이용권역을 구분할 수 있을 것이며, '시설입지의 타당성' 항목에 대해서는 복수의 입지가 검토된 경우 검토 입지의 수만큼 구분하 여 차등 점수를 부여할 수 있을 것이지만 단독 입지만 검토된 경우에는 해당 배점의 $50 \%$ 만 부여 하 는 등의 대안을 정할 수도 있을 것이다.

2) 위험관리 중심의 평가항목 지표기준

[표 5]의 세부평가항목에 대하여 지표기준을 정리하여 [표 8]과 같이 나타내었다.

신공공관리론에 의한 공공건축 경영전략에서 도출한 '주민과의 의견교환체계' 및 '위기관리 대책의 입안 평가' 항목은 제시된 평가지표의 수행 개수 등으로 평가 점수를 부여할 수 있을 것이다.

[표 8] 위험관리 중심의 평가항목 지표기준

\begin{tabular}{c|l}
\hline \multicolumn{1}{c|}{ 세부평가항목 } & \multicolumn{1}{c}{ 지표기준 } \\
\hline 주민과의 의견교환체계6) & $\begin{array}{l}\text { 주민과의 의견교환채널로서 공공참여(PI) 또는 워크샵을 수행하였는지, 지속적인 체제구 } \\
\text { 축을 하였는지 }\end{array}$ \\
\hline 위기관리 대책의 평가 & $\begin{array}{l}\text { 위기발생시 피해의 크기와 위기관리 매뉴얼 등 대응책 마련, 위험발생 가능요소 및 그 } \\
\text { 발생가능성 정도제시, 위기관리 대책 }\end{array}$ \\
\hline 근린관련의 분쟁 방지 & 민원발생빈도, 인근 근린관련 시설과의 중복성 \\
\hline
\end{tabular}

5) 충남발전연구원, 투자심사개선방안, 1998, P34. 
3) 운영관리 중심의 평가항목

[표 6]의 세부평가항목에 대하여 지표기준을 정리하여 [표 9]와 같이 나타내었다.

'생애주기비용' 항목은 여러 비교사업에 대하여 시행건립 사업의 비용비율을 평가지표로 활용할 수 있을 것이며, '자산 건물가치 평가' 항목은 현재 주로 사용하고 있는 할인기간인 20년을 기준으로 20년간 부동산 평균 상승률을 기준하여 평가지표로 사용할 수 있을 것이다.

[표 9] 운영관리 중심의 평가항목 지표기준

\begin{tabular}{l|l}
\hline \multicolumn{1}{c|}{ 세부평가항목 } & \multicolumn{1}{c}{ 지표기준 } \\
\hline 재무적 수익성7) & 내부수익률 \\
\hline 경제적 수익성(파급효과)8) & B/C Ratio, 사업별 파급효과(영향력 계수) \\
\hline 생애주기비용 (LCC, $)$ & 동등사업과 생애주기 비용비교 \\
\hline 자산 건물가치 평가 & 부동산 평균 상승률 \\
\hline 주민과의 의견교환체계 & $\begin{array}{l}\text { 주민과의 의견교환채널로서 공공참여(PI) 또는 워크샵을 } \\
\text { 수행하였는지, 지속적인 체제구축을 하였는지 }\end{array}$ \\
\hline 운영조직 및 운영형태 적합성 & 인력비율(시행사업/비교사업), 운영체제 \\
\hline 시설활용계획 및 주요사업 내용 & 우수, 보통, 미흡 \\
\hline 수요추세 등 발전전망 분석 & 전국평균대비율 \\
\hline 지구환경대책의 평가 & 동등사업과 탄소배출량 비교 \\
\hline
\end{tabular}

\section{4. 결론}

본 제안은 크게 다음의 내용으로 진행되었다.

현행 공공건축사업 투융자심사제도의 한계를 이론적으로 살펴보고, 타당성 조사 보고서를 검토 및 사후 비교 평가 분석하였다. 이를 통해 현행 평가기준의 문제점을 도출하고 개선을 위하여 재정 사업 투자심사 평가항목을 건설사업 전에 초기투자를 중심으로 하는 보수적 관점의 항목, 건설 중 에 나타나는 위험관리를 중심으로 하는 적극적 관점의 항목, 그리고 건설 후에 운영관리를 중심으 로 국가정책에 부응하며 시대흐름에 맞는 지속가능성 관점의 항목으로 생애주기를 고려한 다양한 평가항목의 기준과 생애주기 세부평가항목에 대한 지표기준을 제안하였다.

한편, 건축시설 유형별 평가기준의 가중치가 다르게 나타날 것이므로 평가기준을 일반화하기 위해 서는 이에 대한 후속연구가 필요할 것이다. 또한 본 연구의 한계로써 세부평가항목의 지표기준을 마 련하여 타당성 결과에 대한 신뢰도를 높이고 추진력을 얻게 하기 위하여 노력을 하였으나, 실무에 적용을 하기위한 지표기준은 많은 자료의 통계적인 분석이 요구되는 바 이에 대하여는 향후 심도 있 는 연구가 이루어져야 할 과제이다. 또한 본 연구에서 제안한 생애주기 관점의 평가항목은 이전의 평가기준에는 없던 새로운 항목이므로 현재로서는 이에 대한 평가가 이루어진 연구가 없어 이의 평가결과에 대해서도 향후 연구되어야 할 과제이다. 더불어 평가기준을 계량화한 이후에는 건축시 설 유형별 평가점수를 종합하여 합격선의 기준을 마련하고 이에 따라 타당성 여부를 검토할 필요 도 있다.

6) 財團法人建築保全センター, NPMによる 公共建築の經營戰略，株式會社大成出版社，2003.3，p.24-26，147.

7) 충남발전연구원, 투자심사개선방안, 1998, P34.

8) 임성일, 지방투자심사제도의 개선방안, 한국지방재정공제회, 지방재정, Vol.2003 No.3, 2003. 